\title{
The Commodification of Islam?: A Critical Discourse Analysis of Halal Cosmetics Brands
}

\author{
MANMEET KAUR \\ BHARATHI MUTTY \\ Faculty of Arts and Social Science, Universiti Tunku Abdul Rahman, \\ 31900 Perak, Malaysia \\ *Corresponding author: manmeetk@utar.edu.my
}

Published online: 30 December 2016

To cite this article: Manmeet Kaur and Bharathi Mutty. 2016. The commodification of Islam?: A critical discourse analysis of halal cosmetics brands. KEMANUSIAAN the Asian Journal of Humanities 23(Supp. 2): 63-80, https://doi.org/10.21315/kajh2016.23.s2.4

To link to this article: https://doi.org/10.21315/kajh2016.23.s2.4

\begin{abstract}
Although many studies have emerged examining media representations of Muslims and Islam through the lens of discourse analysis, it is unfortunate that similar studies focusing on glocalised marketing strategies targeted at Muslims have been scarce, especially at a time when market research analysts have identified Muslims as constituting one of the fastest growing consumer segments in the world. In order to tap into this promising market, a number of cosmetics companies have left no stones unturned in their efforts to convince Muslim consumers that their products are Shariah-compliant. Whether or not this claim has any truth value, it is persuasive, as it raises awareness about the existence of halal cosmetics. In line with this, the present study examined the linguistic and non-linguistic semiotic features employed by the halal cosmetics companies to promote their products to Muslim consumers in order to expose the dominant discourses, underlying meanings and hidden ideologies. A qualitative research design was employed to study the marketing websites of five halal cosmetics companies. Analysis was carried out using Fairclough's (1992) threedimensional model of critical discourse analysis. Findings call attention to the commodification of Islam, revealing how marketers are transforming cosmetics into powerful symbols representing religious correctness and values, indices of one's piety.
\end{abstract}

Keywords and phrases: critical discourse analysis, glocalised marketing, halal, cosmetics, beauty 


\section{Introduction}

Baudrillard $(2005,132)$ puts forth the notion that in this day, time and age "beauty has become an absolute religious imperative" for women. This is because, in a patriarchal society like ours, "a woman's value is often associated with how she looks" (McConatha and Volkwein-Caplan 2012, 142). Physically attractive women are perceived "more favourably", regarded as "more desirable" and considered "more successful" (Yan and Bissell 2014, 195). Hence, the neverending quest for ideal beauty via cosmetics. According to the European Union Cosmetics Regulation (2009), a cosmetic product can be defined as:

....any substance or mixture intended to be placed in contact with the various external parts of the human body (epidermis, hair system, nails, lips and external genital organs) or with the teeth and the mucous membranes of the oral cavity with a view exclusively or mainly to cleaning them, perfuming them, changing their appearance and/or correcting body odours and/or protecting them or keeping them in good condition.

The continuous and escalating growth of the beauty industry as manifested by the many cosmetics companies mushrooming worldwide provides a testament for the tyranny of the ideal beauty myth. These companies employ various marketing strategies - utilising a myriad of linguistic and non-linguistic semiotic features creatively - to attract the attention of, persuade and influence women in order to sell their products. Take for instance the use of well-known slogans which are not only catchy and memorable, but also emotionally-oriented and persuasive such as Maybelline's "Maybe she's born with it, maybe it's Maybelline" and Loreal's "Because you're worth it".

The resurgence of fundamentalist activities of major religions in the 1990s, including that of Islam, provided another platform for cosmetics companies to sell their products (Shirazi 2010). Take for instance understanding of the concept halal (permissible - in line with Islamic law) which extended beyond food to include cosmetics, pharmaceutical products, tourism, toys, furniture, clothing, entertainment and etc., encouraging Muslims to choose carefully so as to "achieve Islamically correct behavior" (Hunter 2012, 37). In order to tap into this promising market, a number of cosmetics companies have left no stones unturned in their advertising efforts to convince Muslim consumers that their products are Shariah-compliant, emphasising on the halal status of their products. Whether or not this religious claim has any truth value, it is most certainly persuasive, as it successfully raises greater awareness about the existence of halal cosmetics and 
hence, elevates concerns among Muslim consumers over whether cosmetics used by them are halal.

Although a plethora of studies have emerged examining advertising strategies employed by renowned brands such as Maybelline, L'Oréal, Revlon and Dior in the marketing of their beauty products through the lens of critical discourse analysis, it is unfortunate that similar studies focusing on ethnic marketing targeted at Muslims have been scarce, especially at a time when market research analysts have identified Muslims as constituting one of the fastest growing consumer segments in the world (Iqbal et al. 2014; Baig 2013; Kaur et al. 2013). Underlying the ethnic marketing strategy is the notion of glocalisation. The word glocalisation is a blend of globalisation and localisation. It encompasses "a hybrid strategy that embraces elements of global culture and integrates them into the local culture" (Rajagopal 2015, 7). For the purpose of this study, the term glocalisation refers to the manner in which the selected cosmetics companies, on the one hand, propagate and consolidate the globalised ideal of feminine beauty which is largely based on the western standard and, on the other hand, adapt their products to conform to the cultural expectations and value systems of Muslim consumers. The purpose of this study then is to address the gap in literature through careful examination of the employment of marketing strategies in the form of linguistic and non-linguistic semiotic features by companies which claim that the cosmetics they produce are halal in order to expose the dominant discourses, underlying meanings and hidden ideologies.

\section{Critical Discourse Analysis}

Critical discourse analysis (CDA) is defined as "a theoretical perspective on language and more generally semiosis as one element of the material social process, which gives rise to ways of analysing language or semiosis within broader analyses of the social process..." (Fairclough 2001, 121). It attempts to explain that a discourse is never neutral. Rather, it is almost always heavily laden with specific ideologies, meanings and values. As such, it can be used to sustain and aid dominance, prejudice and subjugation in society. Hence, a discourse can be regarded as a vessel through which aspects of power, hegemony and ideology are made palpable to others. A critical discourse analysis of halal cosmetics brands then aims at "analysing opaque as well as transparent structural relationships of dominance, discrimination, power and control" between cosmetics producers and potential customers, as manifested in the selected discourses, paying close attention to both linguistic and non-linguistic semiotics features employed in order to uncover possible hidden agendas and ideologies at work (Wodak 2001, 2). 


\section{Fairclough's three dimensional model}

This study incorporates Fairclough's (1992) three-dimensional model for CDA, one of the most well-known and widely-used frameworks in the field. This model assembles three analytical dimensions which are interwoven with one another as depicted in Figure 1: (1) analysis of text, (2) analysis of discursive practice and (3) analysis of social practice.

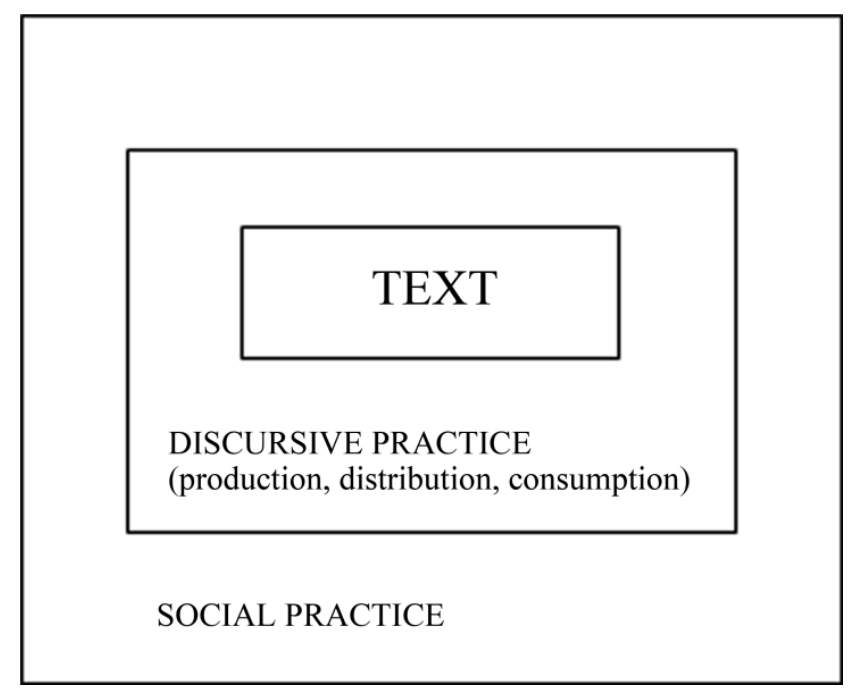

Figure 1. Fairclough's (1992) three-dimensional model

The first analytical dimension is concerned with "the tradition of close textual and linguistic analysis within linguistics" (Fairclough 1992, 72). In other words, the first stage involves detailed textual analysis comprising an elaborate description of the elements that make up a text. For the purpose of this study, the subsequent categories guide in the task of text analysis: (1) vocabulary, (2) grammar, (3) cohesion and (4) text structure. It is imperative to study these features as they are "multifunctional"-"a combination of ideational, interpersonal (identity and relational) and textual meanings" as individuals engage in the deliberate use of specific linguistic items which "signify (and construct) social identities, social relationships and knowledge and belief" (Fairclough 1992, 76). In this study, the first level of analysis is performed to investigate the linguistic features utilised by the selected halal cosmetics companies in order to make their products appealing to targeted consumers.

The second analytical dimension is concerned with discursive practices that encompass "text production, distribution and consumption" in society (Fairclough 1992, 78). It is important to note that these processes differ not only according to 
the genre of the discourse, but also depending on a range of social factors. At this level of analysis, emphasis is placed on the manner in which available existing resources of members comprising "effectively internalised social structures, norms and conventions" are drawn upon by the producers of selected texts in order to come up with effective marketing strategies that can tug at the hearts, minds and purse strings of potential consumers (Fairclough 1992, 80).

The third analytical dimension is concerned with discourse as a social practice. It entails the study of discourse with respect to notions of ideology and power, positioning it steadfastly within hegemony. Fairclough and Wodak $(1997,258)$ further explained that discourse both shapes and is shaped by society-either reflecting, reproducing or sustaining power relations, ideologies and hegemony in a particular context:

Describing discourse as social practice implies a dialectical relationship between a particular discursive event and the situation(s), institution(s) and social structure(s) which frame it. A dialectical relationship is a two-way relationship: the discursive event is shaped by situations, institutions and social structures, but it also shapes them.... Since discourse is so socially influential, it gives rise to important issues of power. Discursive practices may have major ideological effects: that is, they can help produce and reproduce unequal power relations ...through the ways in which they represent things and position people.

In this study, analysis at this level focuses on the manners in which the selected discourses both affect and are affected by social practices or dominant ideologies.

\section{Research Objectives}

The research objectives for the study are as follows:

1. To examine the linguistic features employed to promote the selected international halal cosmetics brands and products

2. To examine the non-linguistic semiotic features employed to promote the selected international halal cosmetics brands and products

3. To examine what the linguistic and non-linguistic semiotic features employed can reveal about the dominant discourse(s) and its underlying ideology(s) as constructed by the halal cosmetics producers

\section{Methodology}

The qualitative research paradigm was employed for the purpose of this study. A qualitative design was deemed appropriate because of the descriptive and 
interpretative nature of this research, which sought to examine linguistic and nonlinguistic semiotic features employed to promote selected halal cosmetics and expose underlying ideologies. Creswell $(2013,48)$ affirmed that a qualitative research method is appropriate when "complex, detailed understanding" and "rich, thick description" of a phenomenon are needed.

A purposive sample of five cosmetics companies was chosen for the study as depicted in Table 1. These companies were chosen based on two criteria: (1) these companies explicitly state that their products are halal and (2) the products from these companies are accessible worldwide. Data were collected from the marketing websites of these companies. Webpages from each website were printed and a manual, paper-and-pencil qualitative content analysis was conducted. For the purpose of this study, qualitative content analysis involved "subjective interpretation" of textual and visual units of meaning "through the systematic classification process of coding and identifying themes or patterns" (Hsieh and Shannon 2005, 1278).

In order to examine the linguistic features employed to promote selected halal cosmetics and expose dominant discourses and underlying ideologies, a careful textual analysis of each webpage was conducted in order to understand both the manifest and latent meanings communicated. Data coding and textual analysis were based on a rubric for linguistic analysis developed by Janks (2005), derived from Fairclough's (1995) approach to CDA. On the basis of the objectives of the study and emerging information collected from the websites, only selected linguistic features from the rubric were utilised. They include (1) lexicalisation choice of words, (2) indirect speech - expressed meaning vs. implied meaning, (3) sentence types and moods - declarative, interrogative, imperative, exclamatory, (4) modality - degrees of uncertainty, (5) pronouns - first, second, third person/inclusive or exclusive and (6) sequencing of information - text structure/logic of argument (Janks 2005).

In order to examine the non-linguistic semiotic features employed to promote selected halal cosmetics and expose dominant discourses and underlying ideologies, a careful visual analysis of each webpage was conducted in order to understand both the manifest and latent meanings communicated. Data coding and visual analysis were based on a rubric developed by Kress and van Leeuwen (2006) for CDA. On the basis of the objectives of the study and emerging information collected from the websites, only selected visual features from the rubric were utilised. They include (1) descriptors - description of visual elements and (2) symbolic attributes - religious imagery (Kress and van Leeuwen 2006). 
Table 1. Selection of cosmetics companies

\begin{tabular}{|c|c|c|c|c|c|}
\hline No. & Brand & $\begin{array}{c}\text { Year } \\
\text { established }\end{array}$ & Cosmetics range & Base & Website \\
\hline 1 & $\begin{array}{l}\text { Saaf } \\
\text { Skincare }\end{array}$ & 2004 & Bodycare, skincare & UK & $\begin{array}{l}\text { http://www.saafskincare. } \\
\text { com/about/ }\end{array}$ \\
\hline 2 & $\begin{array}{l}\text { Sampure } \\
\text { Minerals }\end{array}$ & 2009 & Make up & UK & http://sampure.co.uk/ \\
\hline 3 & $\begin{array}{l}\text { Amara } \\
\text { Halal } \\
\text { Cosmetics }\end{array}$ & 2011 & Make up & US & $\begin{array}{l}\text { https://amaracosmetics. } \\
\text { com/ }\end{array}$ \\
\hline 4 & $\begin{array}{l}\text { The Halal } \\
\text { Cosmetics } \\
\text { Company }\end{array}$ & 2013 & Bodycare, skincare & UK & $\begin{array}{l}\text { http://www.halalcosco. } \\
\text { com/ }\end{array}$ \\
\hline 5 & $\begin{array}{l}\text { Iba Halal } \\
\text { Care }\end{array}$ & 2014 & $\begin{array}{l}\text { Makeup, bodycare, } \\
\text { haircare, skincare }\end{array}$ & India & $\begin{array}{l}\text { http://www.ibahalalcare. } \\
\text { com/ }\end{array}$ \\
\hline
\end{tabular}

\section{Results and Discussion}

The following sections present a detailed textual and visual analysis of the marketing websites of the five selected halal cosmetics companies based on Fairclough's (1992) three-dimensional framework for CDA with regard to the research objectives for the study. As previously explained, CDA relates textual and visual evidence to "discursive practices, events and texts" and "wider social and cultural structures, relations and processes", to shed light on "how such practices, events and texts arise out of and are ideologically shaped by relations of power" (Fairclough 1995, 132). As such, the analysis is presented at three levels, focusing specifically on textual elements, discursive practices and social practices.

\section{Discourse-as-text}

At the first level of analysis, prominent linguistic features employed in the websites are discussed. Vocabulary items play a central role in developing the image of a brand or product through the practice of ascribing, describing and naming. Detailed examination of the websites revealed that while the usage of positive words are especially frequent and popular, the usage of negative words are uncommon and rare as depicted in Table 2. Positive vocabulary items are preferred as they are linked to positive connotations, resulting in a positive outlook of a particular brand or product (Kalmane 2012). Positive adjectives, for instance, impart globalised ideals of beauty (e.g., fairer, flawless, youthful), communicate localised brand values which are in line with Islamic beliefs and teachings (e.g., pure, clean, ethical) and convey the overall mood and tone, which 
in this case is one of peace, security and serenity at not having to compromise between beauty and religion. In addition, they highlight positive attributes, properties and qualities of brand and products as illustrated in the sentence "The potent, purifying and sebum-regulating botanicals in Saaf's Organic Complexion Boosting Serum help to balance oily skin, clear breakouts, smooth away blemishes and improve skin tone and texture". Positive verbs are also employed to emphasise on what the products do, promoting their usefulness to readers as illustrated in the sentence "Iba's refreshing Aloe Aqua ${ }^{T M}$ formula is created to purify, soothe and hydrate your skin..." In order to make the written text succinct yet interesting, a number of novel positive compounds such as "all-naturalorganic", "moisture-adjusting" and "lip-loving" are also used freely as modifiers. According to Thorne $(2008,302)$, "modifiers are a distinctive feature of advertising language because of their power in attracting attention". Such descriptive language "with a high degree of inherent expressivity" has the power to create a positive and successful glocal brand image, personality and perception, elevating a brand beyond mere product functionality or its utilitarian role (Srpová 2007, 139). In the event in which negative adjectives are employed, they are usually associated with pre-existing skin conditions which are deemed undesirable, but can be improved through the usage of the promoted products.

Table 2. Vocabulary items employed in websites

\begin{tabular}{ll}
\hline Vocabulary items & Examples \\
\hline Positive adjectives & $\begin{array}{l}\text { pure, natural, safe, clean, hygienic, healthy, ethical, organic, premium, } \\
\text { luxurious, innovative, revolutionary, authentic, unique, perfect, } \\
\text { flawless, beautiful, youthful, amazing, refreshing, fabulous, fairer, } \\
\text { lighter, younger }\end{array}$ \\
Positive verbs & $\begin{array}{l}\text { cleans, softens, soothes, replenishes, cools, tones, refreshes, } \\
\text { moisturises, prevents, protects, conditions, strengthens, purify, } \\
\text { hydrate, reduce, restore, smooth, nourish, nurture, reverse, improve }\end{array}$ \\
Positive compounds & $\begin{array}{l}\text { eco-ethical, worry-free, chemical-free, all-natural-organic, skin- } \\
\text { pampering, moisture-adjusting, long-lasting, super-saturated, healthy- } \\
\text { looking, lip-loving, cutting-edge, ultra-pigmented }\end{array}$ \\
Negative adjectives & oily, dry, rough, coarse, cracked, inflammatory, irritating \\
\hline
\end{tabular}

An examination of the websites also revealed the presence of weasel words and phrases as depicted in Table 3. At first look, weasel expressions seem meaningful and substantial. However, upon close scrutiny, ambiguous, meaningless and misleading expressions are discovered. According to Shaw $(2016,221)$, such expressions are employed "to evade or retreat from a direct or forthright statement". They are used "to avoid having to prove or disprove a claim" in the event of a dispute (Shams 2013, 115). Take for instance, the weasel word "help" as depicted in Sentence 1 in Table 3. The word "help" here means "aid", "assist" 
or "support" and nothing more than that. It does not promise to cure or stop skin problems, but indicates a mere possibility of reducing problematic skin conditions. In the same vein, the word "fight" as depicted in Sentence 2 in Table 3 means "battle" or "combat" and nothing more than that. It does not necessarily and successfully cure, prevent or stop the appearance of blemishes. Shaw (2016, 317 ) stated that "on hearing or reading a claim containing a weasel word, we tend to screen out the weasel word and just hear the claim". Even more so when the discourse makers divert attention away from the weasel expressions to women's insecurity of not living up to the global beauty ideal, coaxing them to purchase cosmetics as a remedy. Kalmane $(2012,87)$ affirmed that "covert inferences are processed unconsciously and therefore can affect the audience without them noticing it". Similarly, although the weasel phrase "studies show" as depicted in Sentence 3 in Table 3 provides an illusion that a well-researched and scientifically-based argument or statement is being levelled out, the truth is that the statement is rather vague, without any actual and specific details, evidence or proof of the study being provided. In this case, the discourse makers divert attention to Muslim women's insecurity of not adhering to Islamic tenets, coaxing them to purchase halal cosmetics as a remedy.

Table 3. Weasel expressions employed in websites

\begin{tabular}{lll}
\hline $\begin{array}{l}\text { Weasel } \\
\text { expressions }\end{array}$ & Examples \\
\hline Weasel words & 1. & $\begin{array}{l}\text { "Saaf's Organic Complexion Boosting Serum helps to balance } \\
\text { combination or oily skin..." } \\
\text { "Lemon Extract and Vitamin B3 fights blemishes." (Iba Halal Care) }\end{array}$ \\
Weasel phrases & 2. & $\begin{array}{l}\text { "Studies show that women who apply lipstick end up 'eating' the } \\
\text { lipstick they've applied... So, imagine all those lipsticks products } \\
\text { currently out in the market that are made with chemicals ... as well } \\
\text { as other items, like alcohol or ingredients that are extracted from } \\
\text { animals like pigs." (Amara Halal Cosmetics) }\end{array}$ \\
& 4. & $\begin{array}{l}\text { "Clinical trials have shown that Astaxanathin protects the skin whilst } \\
\text { allowing it to regenerate ... thereby causing a significant reduction of } \\
\text { wrinkles and puffiness." (The Halal Cosmetics Company) }\end{array}$ \\
\hline
\end{tabular}

Besides that, it was observed that the descriptive pattern is the most commonly employed text structure type in the selected discourses. Generally, declarative sentences are used to convey detailed brand, company and product information. Emphasis is often placed on the quality of the products, what they can achieve and their halal-status. Parallel structures are heavily used "to add emphasis, clarity, balance and cumulative weight", enhancing persuasiveness by conveying "the spontaneous energy of deep feeling or conviction" as exemplified in the following sentence extracted from the Saaf Skincare website (Cockcroft and Cockcroft 2014, 106): "Our founder, Dr Mah, draws on her in-depth homeopathic 
and pharmacological experience to formulate botanicals into blends which help smooth lines, soothe blemishes, nourish dryness, nurture fragilities and restore natural balance".

Occasionally, the problem-solution text structure is employed, as exemplified in the excerpt below, taken from the Iba Halal Care website. A rhetorical question emphasising on an existing problem is posed in anticipation of confirmation from the target audience. Usage of the second person pronoun aims to address the target audience personally and directly, enhancing affective appeal, in order to capture the attention of the audience. The answer to the question is provided by the discourse maker in the form of a product which provides a solution to the aforementioned problem. The rhetorical question can be regarded as an indirect speech act. Although it seems that a question is being posed, the reality is that a statement or an assertion is being made through the use of a loaded question in order to attract attention, prompt cognitive processing and enhance persuasion by addressing glocal concerns which are relevant to the target audience. For instance, on the one hand, the producers draw on the global woman's desire for healthy hair/scalp and on her fear of hair loss. On the other hand, the producers adapt their discourse to specifically address such concerns faced specifically by Muslim women who keep their hair covered.

Do you experience your hair becoming greasy, sweaty and itchy because it remains covered for long? Oil, sweat and excess sebum damage scalp, leading to dandruff and hair fall. Introducing Iba Covered Hair range of shampoo and hair oil. Enriched with Kalonji (Black Seeds), Amla, Aloe and Neem, Iba Covered range of products effectively control excess sebum, prevent dandruff and reduce hair fall.

Language mixing can also be observed. Take for instance, the insertion of the non-Anglo-English word kalonji instead of its English equivalent "nigella sativa" or "black cumin" in the last sentence of the excerpt above to account for a culture-specific lexical item that the target audience is more familiar with, hence, enhancing persuasive appeal. Within the Muslim culture, kalonji has great significance as Prophet Muhammad once stated that it can be used to cure any disease, except for death (Saad and Said 2011). Other culture-specific lexical items employed in the discourses under study include halal, haram, wuzu and attar. 


\section{Discourse-as-discursive practice}

At the second level of analysis, the various marketing strategies employed by the selected halal cosmetics companies to attract, persuade and influence Muslim customers as depicted in their marketing websites are discussed.

Table 4. Arabic/religious terminologies employed in websites

\begin{tabular}{|c|c|}
\hline $\begin{array}{l}\text { Arabic/Religious } \\
\text { terminologies employed }\end{array}$ & Examples \\
\hline \multirow[t]{4}{*}{ Halal } & $\begin{array}{l}\text { The term halal which means permitted in Arabic appears as a } \\
\text { co-brand in the following: }\end{array}$ \\
\hline & 1. Amara Halal Cosmetics \\
\hline & 2. Iba Halal Care \\
\hline & 3. The Halal Cosmetics Company \\
\hline \multirow[t]{2}{*}{ Amara } & $\begin{array}{l}\text { The Arabic word Amara is a name for a Muslim female which } \\
\text { means "eternal beauty, lasting forever, always existing and } \\
\text { unfading". It appears as a co-brand in the following: }\end{array}$ \\
\hline & 1. Amara Halal Cosmetics \\
\hline \multirow[t]{2}{*}{$I b a$} & $\begin{array}{l}\text { The Arabic word } I b a \text { means self-esteem. It is also a name for a } \\
\text { Muslim female which means dignified yet reserved and } \\
\text { exalted yet sublime. It appears as a co-brand in the following: }\end{array}$ \\
\hline & 2. I Iba Halal Care \\
\hline \multirow[t]{2}{*}{ Saaf } & $\begin{array}{l}\text { The word Saaf which means pure in Arabic/Persian appears as } \\
\text { a co-brand in the following: }\end{array}$ \\
\hline & 3. Saaf Skincare \\
\hline
\end{tabular}

One of the most prominent strategies employed is that of Islamic branding. According to Noor $(2010,19)$, Islamic branding comprises "branding that is empathetic to shariah values, in order to appeal to the Muslim consumer, ranging from basic shariah-friendliness to full shariah-compliance in all aspects of a brand's identity, behaviour and communications". Alihodzic (2013) explains that the name of a brand has the power to ensure visibility, enhance awareness, improve recognition and influence perception. As such, in order to effectively target Muslim consumers, Arabic or religious terminologies are used in the names of the cosmetics companies as depicted in Table 4. On the one hand, this strategy of glocalisation through language mixing (English and Arabic) is particularly advantageous in a brand being perceived as Islamic, as it not only reduces consumer distance and mistrust, but also builds credibility and desirability through reassurance. On the other hand, however, usage of religious terms such as halal imply some form of commodification as religion is being 
used for commercial purposes. For instance, Wilson and Liu (2010, 109) assert that the usage of the term halal to market non-food products marks "a departure from basic Islamic principles - where everything is halal, unless stated otherwise".

Additionally, in order to attract Muslim consumers, these companies have built their brands upon universal Islamic values such as cleanliness, ethics, purity, safety and peacefulness as depicted in Table 5. As these material products are associated with Islamic values, their worth increases because the brand becomes more favourably perceived by Muslims. This is supported by the findings of a study conducted by Alihodzic (2013) which revealed that Muslim consumers have a positive perception of and a strong purchasing pattern from brands that reflect or support their values. Such a practice results in "the monetisation of values" - "a phrase which denotes a process whereby religious values have their sacred quality compromised by being reduced to monetary equivalents in the form of products for sale" (Merelman 1984, 137). At this point, it is important to note that cosmetics that carry halal labels (as opposed to halal certification which may also raise concerns given the many halal certification bodies and the different denominations of Islam around the world) do not necessarily translate into pure, natural, organic or safe products and that pure, natural, organic or safe products do not necessarily translate into better, effective or quality products.

Some of these companies have even gone to the extent of creating product lines that target a specific group of Muslims with specific belief systems. For instance, Iba Halal Care carries a range of hair care products specifically formulated for Muslim women who keep their hair covered with a scarf, hijab or burqa. The producers of the selected discourse postulate that wearing a veil can cause scalp problems, which in turn, lead to hair loss and therefore, offer a solution in the form of their one-of-a-kind conditioning shampoo and hair oil: "Iba covered range of products effectively control excess sebum, prevent dandruff and reduce hair fall". At first glance, such a claim may seem convincing, however, it is not without problems. For instance, the claim that wearing a veil can result in scalp conditions can be challenged and questioned as it is unsubstantiated. Moreover, usage of the weasel word "control" is observed in the excerpt drawn from the selected discourse. The word "control" is neither synonymous with curing the existing condition or eliminating the root cause of the problem, nor does it specify precisely as to what extent the problem can be controlled, in the event that it can be controlled. Since the product is unable to put a stop to the problem, but merely control it, there is a high possibility that this would result in consumer dependency on the product. As such, Shirazi $(2016,217)$ rightly observed that "some manufacturers actually exploit the Muslim hijab to market shampoo and other hair cleansing and styling products". 
Table 5. Islamic values drawn upon in websites

\begin{tabular}{|c|c|}
\hline Islamic values & Examples \\
\hline \multirow[t]{2}{*}{ Cleanliness } & $\begin{array}{l}\text { 1. "Clean and hygienically made to deliver superior quality." } \\
\text { (Iba Halal Care) }\end{array}$ \\
\hline & $\begin{array}{l}\text { 2. "Amara Halal Cosmetics provides its customers with pure, clean, } \\
\text { cosmetic products." }\end{array}$ \\
\hline \multirow[t]{2}{*}{ Ethics } & $\begin{array}{l}\text { 1. "We are against any animal testing as we do not see why an animal } \\
\text { should suffer for the sake of our beauty." (The Halal Cosmetics } \\
\text { Company) }\end{array}$ \\
\hline & $\begin{array}{l}\text { 2. "Iba Halal Care embraces an eco-ethical philosophy; Iba products are } \\
\text { not merely natural but also pure and hygienically manufactured, } \\
\text { vegan and animal cruelty free." }\end{array}$ \\
\hline \multirow[t]{2}{*}{ Purity } & $\begin{array}{l}\text { 1. "Here at The Halal Cosmetics Company we have ensured that all our } \\
\text { products are halal, this means that we have refrained from using any } \\
\text { haram animal substances in our products." }\end{array}$ \\
\hline & $\begin{array}{l}\text { 2. "Saaf's products are } 100 \% \text { Natural; free from artificial fragrances and } \\
\text { colourings, free from common allergens and irritants, as well as } \\
\text { being Alcohol, GMO and Irradiation free and Halal approved." }\end{array}$ \\
\hline \multirow[t]{2}{*}{ Safety } & $\begin{array}{l}\text { 1. "Sampure Minerals range is formulated using healthy mineral } \\
\text { foundations and powders that are naturally FREE from animal } \\
\text { products, harsh chemicals, talc, bismuth oxychloride, mineral oil } \\
\text { (and its derivatives), paraben preservatives, alcohol, petroleum } \\
\text { derived ingredients, fillers, lanolin or any other animal products." }\end{array}$ \\
\hline & $\begin{array}{l}\text { 2. "Celebrating, chemical, allergen and fragrance free skincare." } \\
\text { (Saaf Skincare) }\end{array}$ \\
\hline \multirow[t]{2}{*}{ Peacefulness } & $\begin{array}{l}\text { 1. "Salma began her journey to develop a skincare and cleansing range } \\
\text { which was ethical in every possible way without compromising on } \\
\text { luxury and quality... A range which truly offers, PEACE of mind } \\
\text { from dawn till dusk." (The Halal Cosmetics Company) }\end{array}$ \\
\hline & $\begin{array}{l}\text { 2. "Sampure Minerals range is approved by the Vegetarian society } \\
\text { offering complete peace of mind..." }\end{array}$ \\
\hline
\end{tabular}

Similarly, although Kamali (2013, 35) asserted that "only ethyl alcohol is intoxicating and therefore haram" and that "there is no problem in using perfumes or scents in which alcohol is used as a solvent for the manufacturing of fragrances or aromatic substances, or in using body lotions which contain alcohol", all of the selected companies emphasise on the "alcohol-free" or "fragrance-free" status of their products when marketing, with Iba Halal Care even offering a range of alternative alcohol-free fragrances in the form of attars which are commonly used in mosques. Wudhu-friendly products are also introduced by some of these companies such as Iba Halal Care and Sampure Minerals in the form of make-up, nail polishes and skincare products. However, further details and evidence explaining how and what make these products 
wudhu-friendly, breathable and water permeable ensuring a hassle-free and valid ablution are not given.

The appropriation of religious imagery is also observed. Take for instance, the usage of symbols such as the crescent moon and star which are closely associated with Islam in the logo of The Halal Cosmetics Company. Besides that, usage of the colour green which symbolises not only "righteousness and piety", but is also associated with "angels and paradise in Islam", is employed both in the logo of Saaf Skincare and The Halal Cosmetics Company (Sirriyeh 2015, 106). In the same vein, the logo for Iba Halal Care employs the motif of "a flowering water droplet" which "connotes beauty that blooms through cleansing", emphasising on cleanliness and hygiene which are important tenets in Islam.

Finally, careful examination of the websites revealed the presence of causedriven marketing which can be defined as a promotional strategy in which a company is linked to a specific social or worthwhile local, global or glocal cause. Take for instance Amara Halal Cosmetics which actively "strives to promote awareness in the Muslim community that Halal isn't limited to what is consumed as food but also applies to what is put on our skin". Similarly, Iba Halal Care asserts that "the word Halal may bring the thought of food to mind, but it is actually a universal tenet that applies to all aspect of life and not just food". Companies such as The Halal Cosmetics Company, Sampure Minerals, Saaf Skincare and Iba Halal Care advocate against animal testing and the use of animal derived ingredients, championing for animal rights. While Saaf Skincare is certified cruelty free by Naturewatch and Cruelty Free International, Sampure Minerals is certified cruelty free by the British Union for the Abolition of Vivisection. According to Adkins (2007, 79), cause-driven marketing results in positive consumer perception with a whopping "86 percent of consumers claiming that they would have a more positive image of that company regardless of specific cause or issue being addressed".

\section{Discourse-as-social practice}

At the third level of analysis, the manner in which the selected discourses both affect and are affected by social practices or dominant ideologies are discussed. The notion of intertextuality which refers to the manner in which discourses are "always connected to other discourses which were produced earlier as well as those which are produced synchronically or subsequently" is also discussed (Fairclough and Wodak 1997, 276).

It can be observed that the globalised ideals of beauty dominated by western standards most certainly influence the selected discourses. Firstly, beauty is 
perceived as being synonymous with youthfulness. Thus, the production and marketing of anti-ageing creams and serums that claim that they resist the ageing process, increase the production of collagen and elastin, firm the skin and smooth fine lines. Secondly, beauty is perceived as being synonymous with flawless skin. Thus, the production and marketing of (1) foundation, (2) powder and (3) blemish clearing creams, serums, cleansers and moisturisers that claim that they camouflage flaws, reduce existing imperfections, prevent future imperfections, improve overall skin texture and heal as well as nourish the skin. Thirdly, beauty is synonymous with a fair and radiant complexion. Thus, the production and marketing of fairness creams that claim that they brighten dull skin, lighten skin tone and protect the skin from dangerous ultraviolet rays. Fourthly, products such as lipsticks, eyeliners, eyeshadows and blushers are believed to accentuate the facial features of women, enhancing femininity and increasing social desirability.

Images of young models with perfect skin (no blemishes, scars or pores) and ideal facial features (high eyebrows, double eyelids, round eyes, pronounced nose, high cheekbone, narrow face, full lips) that grace the homepage of the selected marketing websites can evoke feelings of dissatisfaction, lowering the self-esteem of affected women (Yan and Bissell 2014). Working on women's insecurities, marketers create unrealistic expectations and false hopes when they promise "miracle" or "revolutionary" products that result in "instant glowing fairness", "a fresh glow", "the perfect pout", "sensuous lips", "vibrant hair", "a perfect sun kissed glow" and "an overall lit-from-within complexion". Power is exercised by the marketers not only by invoking inadequacies - highlighting existing skin conditions which are perceived as undesirable, but also by manufacturing consent - emphasising on the magical problem-solving properties of their products.

The discourses under study can also be perceived as being gender-biased as the notion of beauty is only associated with women. Moreover, only female models are employed in the discourses. It is also highly unfortunate that as depicted in Amara Halal Cosmetics' website and in line with normative ideas, cosmetics products are associated with helping "young women achieve their utmost potential inside and outside" and "empowering everyday women". A woman's worth should not be judged based on her physical appearance, but based on her capabilities. Similarly, her confidence should come from within, not from the use of and reliance on cosmetics.

In addition, the manner in which the discourse of religion exerts its influence over the discourse of beauty and marketing, resulting in "the fabrication of a transnational Muslim femininity" which is "instrumental in the commodification of Islamic identity politics in the late capitalist global market" can be observed 
(Moallem 2005, 125). The ideal Muslim woman is portrayed as drawing a perfect balance between spirituality and modernity. She is modest and religious, yet attractive and fashionable. Although local ethnic-looking models who don colourful and fashionable headscarves are employed, they carry the idealised global beauty features based on western standards (e.g. fair skin, high eyebrows, double eyelids, round eyes, pronounced nose, narrow face, full lips). They avoid the usage of loud makeup, but opt for natural or pastel make up which results in a soft look. The cosmetics products that they use are a 100 percent halal, pure, clean, hygienic, safe, alcohol-free and cruelty-free, conforming to their religious beliefs. They have to neither compromise beauty, nor religious beliefs. Drawing on Muslim values, catchy slogans such as "Beauty bhi, Halal bhi", "Skin that breathes remains pure", "For real beauty without impurity", "Be natural, be beautiful", "Beauty without compromise" and "Peace of mind from dawn to dusk" are employed to reassure and persuade Muslim consumers.

\section{Conclusion}

Based on the first level of analysis, it could be summarised that the selected halal cosmetics producers use positive vocabulary items which have positive connotations in order to attract and persuade female Muslim customers. In particular, these positive vocabulary items are employed to impart globalised ideals of beauty, communicate localised brand values which are in line with Islamic values and highlight the positive qualities of the cosmetics products. In addition, weasel expressions are utilised to provide an illusion that scientificallybased arguments are presented, when, in reality, vague statements without any evidence are offered. Discourse makers skilfully divert attention away from the weasel expressions by drawing attention to Muslim women's insecurities of not living up to the global beauty ideal and of not adhering to Islamic tenets, coaxing them to purchase halal cosmetics as a remedy. In addition, language mixing is employed to account for culture-specific vocabulary items that the Muslim audience is more familiar with, in order to enhance persuasive appeal. The second level of analysis revealed the presence of Islamic branding as religious imagery, terminologies and values are employed by the selected halal cosmetics companies to cater to the Muslim market. These marketers have a tendency to highlight how their line of cosmetics is synonymous with smart Muslim women who are able to strike a perfect balance between faith and beauty. The third level of analysis exposed the manner in which the selected companies appropriated beauty ideals based on western standards to sell their products by appealing to women's insecurities. As well, they painted a picture of the ideal Muslim woman who successfully achieves a balance between spirituality and modernity through her wise choice of halal cosmetics, not compromising religion for the sake of beauty. To conclude, findings call attention to the commodification of Islam as in their efforts to adopt a glocalised marketing strategy, marketers begin to exploit 
religion for economic gains. Cosmetics are transformed into powerful symbols representing religious correctness and values, indices of one's piety.

\section{References}

Adkins, S. 2007. Cause related marketing. New York: Routledge.

Alihodzic, V. 2013. Brand identity factors: Developing a successful Islamic brand. Hamburg, Germany: Anchor Academic Publishing.

Baig, M. 2013. Analysing the advertising discourse: A journey from sight to mind. International Journal of Applied Linguistics and English Literature 2(1): 126-135, https://doi.org/10.7575/ijalel.v.2n.1p.126.

Baudrillard, J. 2005. The finest consumer object: The body. In The body: A reader, eds. Fraser, M. and Greco, M., 277-283. New York: Routledge.

Cockcroft, R. and Cockcroft, S. 2014. Persuading people: An introduction to rhetoric. Hampshire, UK: Palgrave Macmillan.

Creswell, J. 2013. Qualitative inquiry and research design: Choosing among five approaches. London: Sage Publications.

European Union Cosmetics Regulation. 2009. Regulation no 1223/2009 of the European parliament and of the council on cosmetic products. Retrieved from http://ec.europa.eu/health/endocrine_disruptors/docs/cosmetic_1223_2009_regulat ion_en.pdf.

Fairclough, N. 2001. Critical discourse analysis as a method in scientific research. In Methods of critical discourse analysis, eds. Wodak, R. and Meyer, M., 121-138. London: Sage, https://doi.org/10.4135/9780857028020.n6. 1995. Critical discourse analysis. London: Longman. 1992. Discourse and social change. Cambridge: Polity Press.

Fairclough, N. and Wodak, R. 1997. Critical discourse analysis. In Discourse as social interaction, ed. van Dijk, T. A., 258-284. London: Sage.

Hsieh, H. F. and Shannon, S. E. 2005. Three approaches to qualitative content analysis. Qualitative Health Research 15(9): 1277-1288, https://doi.org/10.1177 /1049732305276687.

Hunter, P. D. 2012. The emerging halal cosmetic and personal care market: Integrating the organisation towards the philosophy of Tawhid. Perlis: Penerbit Universiti Malaysia Perlis.

Iqbal, A., Danish, M. H. and Tahir, M. R. 2014. Exploitation of women in beauty products of Fair and Lovely: A critical discourse analysis study. International Journal on Studies in English Language and Literature 2(9): 122-131.

Janks, H. 2005. Language and the design of texts. English Teaching: Practice and Critique 4(3): 97-110.

Kalmane, R. 2012. Advertising: Using words as tools for selling. Riga, Latvia: Lulu Enterprise Limited.

Kamali, M. H. 2013. The parameters of halal and haram in Shariah and the Halal industry. Richmond, UK: The International Institute of Islamic Thought (IIIT).

Kaur, K., Arumugam, N. and Yunus, N. M. 2013. Beauty product advertisements: A critical discourse analysis. Asian Social Science 9(3): 61-71, https://doi.org/ 10.5539/ass.v9n3p61. 
Kress, G. and van Leeuwen, T. 2006. Reading images: The grammar of visual design. London: Routledge.

McConatha, J. and Volkwein-Caplan, K. 2012. The social geography of healthy aging. Toronto: Meyer and Meyer Verlag.

Merelman, R. M. 1984. Making something of ourselves: On culture and politics in the United States. Berkeley, CA: University of California Press.

Moallem, M. 2005. Between warrior brother and veiled sister: Islamic fundamentalism and the politics of patriarchy in Iran. Berkeley, CA: University of California Press.

Noor, O. 2010. Brands and Muslim consumers. Keynote address by Miles Young, CEO Ogilvy and Mather Worldwide, Oxford Global Islamic Branding and Marketing Forum, 26-27 July, Said Business School, University of Oxford.

Rajagopal. 2015. The butterfly effect in competitive markets: Driving small changes for large differences. New York: Palgrave Macmillan.

Saad, B. and Said, O. 2011. Greco-Arab and Islamic herbal medicine: Traditional system, ethics, safety, efficacy and regulatory issues. New Jersey: John Wiley and Sons, https://doi.org/10.1002/9780470944363.

Shams, M. R. 2013. Newspapers in the ELT classroom: A guide to the English newspaper for ESL/EFL students. Bloomington, IN: AuthorHouse.

Shaw, W. 2016. Business ethics: A textbook with cases. Boston, USA: Cengage Learning.

Shirazi, F. 2016. Brand Islam: The marketing and commodification of piety. Austin, TX: University of Texas Press. 2010. Islam and Barbie: The commodification of Hijabi dolls. Islamic Perspective 3: 10-27.

Sirriyeh, E. 2015. Dreams and visions in the world of Islam: A history of Muslim dreaming and foreknowing. London: I. B. Tauris and Co Ltd.

Srpová, H. 2007. Target group: The decisive factor in the form of advertising. In Persuasion through words and images, ed. Srpová, H., 113-153. Ostrava, Czech Republic: University of Ostrava.

Thorne, S. 2008. Mastering advanced English language. Hampshire, UK: Palgrave Macmillan.

Wilson, J. and Liu, J. 2010. Shaping the Halal into a brand? Journal of Islamic Marketing, 1(2): 107-123, https://doi.org/10.1108/17590831011055851.

Wodak, R. 2001. What CDA is about: A summary of its history, important concepts and its developments. In Methods of critical discourse analysis, eds. Wodak, R. and Meyer, M., 1-13. London: Sage, https://doi.org/10.4135/9780857028020.n1.

Yan, Y. and Bissell, K. 2014. The globalisation of beauty: How is ideal beauty influenced by globally published fashion and beauty magazines? Journal of Intercultural Communication Research 43(3): 194-214, https://doi.org/10.1080/17475759. 2014.917432. 